支部・集談会記事

\section{日本臨床外科学会千葉県支部抄録 (第70回千葉県外科医会)}

\author{
日時：平成26年 3 月 1 日（土） 13：30～ \\ 会場：千葉県医師会 第 1 会議室 \\ (ホテルニューツカモト内 2 階)
}

支 部 長 : 佐藤 裕俊 (千葉県外科医会会長)

当番世話人：丸山 尚嗣

\section{特別講演}

司会：岡住 慎一（東邦大学医療センター佐倉病 院外科)

「より高いクオリティを目指した腹腔鏡下胃癌手術」

国立がん研究センター東病院 胃外科 科長

木下 敬弘先生

司会: 宮澤 幸正 (千葉大学医学部先端応用外科)

「我が国における遺伝性乳がん・卵巣がん (Hereditary Breast and Ovarian Cancer : HBOC) の現状と今後 の対策」

昭和大学医学部外科学講座乳腺外科部門 教授 中村 清吾先生

司会 : 鈴木 一郎（船橋市立医療センター事業管 理者)

「外科における originality と challenge」

千葉大学医学部附属病院長

宮崎＼cjkstart勝先生

\section{1 大腸癌肝転移切除例における化学療法の意義}

聖隷佐倉市民病院 外科

小池直人、大島祐二、武内俊章、安達憲一郎、久保田亨、有田誠 司

手術療法、化学療法の進歩により、大腸癌肝転移の治療成績は 著しく改善している。しかし、切除後の再発率はいまだ高く、更 なる治療成績の改善の為に予後因子の解析、抗癌剤の投与方法を 再検討する必要がある。当院開設 2004 年 3 月から 2013 年12月まで の 9 年 9 ケ月間に我々が経験した肝切除症例は 38 例で、肝切除後 の 5 生率は $44.2 \%$ でった。このうち、Grade別ではA:10例、 B:10例、C:18例であった。Grade別の再発率は A: $30.0 \% 、 B: 80.0 \%$ 、 C:88.9\%、切除後 5 生率は A:87.5\%, B:51.4\%, C:8.4\%でGradeが 進むにつれて有意差をもって悪化した。大腸癌の化学療法はこの 10年間で著しく進歩したが、これらの症例に対して当院で行った 化学療法を再検討しその意義について報告する。

2 非切除胃に発生したgastritis cystica profundaに早期 胃癌が併存した 2 例

千葉県がんセンター 消化器外科

後藤裕磨、鍋谷圭宏、武藤頼彦、滝口伸浩、池田 篤、早田浩明、 外岡 亨、貝沼 修、趙 明浩、柳橋浩男、石神恵美、山本 宏、 永田松夫

Gastritis cystica profunda（GCP）は粘膜下層に及ぶ囊胞状拡
張腺管を特徵とする胃粘膜病変で、Billroth-II法再建後の残胃吻 合部近傍に発生することが多い。腸液逆流等による慢性炎症が発 生の一因とされるが、非切除胃での成因は不明である。今回、70 歳代と60歳代の男性の L 領域分化型 SM 癌（1 例は ESD 後、 2 例 とも pT 1 bN 0 M 0 ）に対して幽門側胃切除術を施行したところ、 癌部と離れたSMT様病変をはじめ体中下部に広がる GCPを認め た。GCPは前癌病変ならびに併存胃癌が多発する可能性が示唆 されている。非切除胃のGCPも念頭に置き多発胃癌の発見に努 め、残胃は入念な経過観察が必要である。若干の考察を加えて報 告する。

3 術前化学療法により根治的切除し得た腸回転異常を伴 う若年性進行膵癌の一例

千葉大学大学院医学研究院 臟器制御外科学

佐々木亘亮、三島 敬、吉富秀幸、中島正之、清水宏明、大塚将 之、加藤 厚、古川勝規、宮崎 勝

症例は43歳、男性。主訴は腹痛。精查にて総肝動脈浸潤を伴う 長径 $50 \mathrm{~mm}$ の局所進行膵頭部癌 ( T $4 \mathrm{~N} 0 \mathrm{M} 0$ cStage IV a) と診断。 同時に腸回転異常症を認めた。術前化学療法 (S- 1 +gemcitabine:GS) を 3 コース施行により、腫瘍縮小し総肝動脈 との境界も明瞭となり根治目的に膵頭十二指腸切除術を施行。病 理学的にも R 0 手術で有り、術後補助 GS 療法を 8 コース完遂し、 治療開始後29个月も無再発生存中。本症例のように、局所進行膵 癌でも術前化学療法が奏功した症例では、手術により予後延長効 果が期待できると考えられる。当施設での術前化学療法後の手術 施行症例を中心に検討し報告する。

\section{4 門脈輪状膵を合併した膵切除症例の検討}

国立がん研究センター東病院 肝胆膵外科

高田暢夫、高橋進一郎、加藤祐一郎、後藤田直人、小西 大

門脈輪状膵（portal annular pancreas）は膵鈞状突起の先端が 膵体部と癒合し上腸間膜静脈や門脈を輪状に取り囲む非常に稀な 膵の形態異常である。門脈輪状膵自体は症状を呈さないが、膵切 除を行う症例扔いてその存在は膵断端面積の拡大や膵鈎部の分枝 膵管の残存等の問題点が指摘されており注意が必要である。当科 ではこれまでに門脈輪状膵合併症例への膵切除を 3 例経験した。 1 例目は46歳女性、転移性膵腫瘍に対して膵体尾部切除術を施行 した。2 例目は72歳女性、中下部胆管癌に対して亜全胃温存膵頭 十二指腸切除術を施行した。3 例目は62歳女性、膵体部癌に対し て膵体尾部切除術を施行した。術前に門脈輪状膵の存在を指摘し 得たのは 3 例中 1 例のみであった。自験例では特に合併症の増加 を認めなかったが、画像診断において常に念頭に置き、門脈輪状 膵合併例に対しては術前に十分にシュミレーションしておくこと が合併症回避のためにも重要であると考えられる。

5 1 例

千葉大学大学院医学研究院 臓器制御外科学

寺中亮太郎、岡村大樹、中村祐介、清水宏明、大塚将之、加藤 厚、 吉富秀幸、古川勝規、高屋敷吏、久保木知、鈴木大亮、酒井 望、 中島正之、宮崎 勝

症例は73歳男性。上部胆管癌に対して肝右葉切除、尾状葉切除、 肝外胆管切除、胆管空腸吻合術施行。術後16か月目に発熱を主訴 に入院。入院後嘔吐あり、腹部 CT にて被囊性腹膜硬化症による 腸閉塞の診断。保存的に加療するも、その後腹痛、顔色不良出現。 
腹部 CTにて門脈気腫を認めたため、緊急手術となった。手術後 37日目に退院となり、現在まで症状の再発を認めていない。被囊 性腹膜硬化症について若干の文献的考察を加えて報告する。

\section{6 盲腸癌による腸重積症の 2 例}

千葉県済生会習志野病院 外科

米浦直子, 鈴木弘文, 山本和夫, 岡屋智久, 杉本克己, 唐木洋一, 佐々木健秀, 山森秀夫, 菅野 勇

成人の腸重積症は比較的稀とされる，今回我々は，腸重積を呈 した盲腸癌の 2 症例を経験したので, 文献的考察を加え報告する.

症例 1 は70歳女性. 便潜血陽性の精査目的に紹介. CTにて上 行結腸に target signを認めた。腸閉塞症状はなく，下部内視鏡 検查を施行した。盲腸癌の診断となり, 右半結腸切除術, D 3 リ ンパ節郭清を施行．病理診断は，重積先進部は $45 \mathrm{~mm}$ 大の 2 型盲 腸癌で, pSS,ly 2 ,v 1 ,pN 3 ,Stage III bであった.

症例 2 は91歳, 男性. 貧血精查目的に紹介. CTにて上行結腸 に target signを認めた。症例 1 と同様に腸閉塞症状はなく, 下 部内視鏡検查にて盲腸癌と診断され, 右半結腸切除術, D 2 リン パ節郭清を施行した. 病理診断は, 重積先進部は $49 \mathrm{~mm}$ 大の 2 型 盲腸癌であり, pSS,ly 1 v 0 ,pN 0 ,Stage II であった.

7 上部消化管造影検査後のバリウム虫垂炎 4 例の検討 千葉メディカルセンター 外科

酒井 敦、高石 聡、佐久間洋一、岩崎好太郎、二村好憲、当間 智子、遠藤悟史、田村真樹、関 幸雄、山本義一

上部消化管造影は胃癌検診として厚生労働省より認定され、今 後も症例数は増加していくものと思われ、その合併症への対応は 非常に重要である。今回我々は上部消化管造影検査後に発症した バリウム虫垂炎を同時期に 4 例経験した。バリウム虫垂炎の定義 として、症状を有し腹部CTにて虫垂の腫大、バリウム貯留、周 囲の炎症所見が認められるものとした。症例はいずれも男性で平 均46歳、バリウム検查後発症まで平均11日間、全例右下腹部痛で 発症。症状の強い 1 例は緊急で虫垂切除術を施行し、他の 3 例は 保存的加療を行った。バリウム虫垂炎は外科医にとっては日常臨 床で遭遇する機会が珍しくないが、上部消化管造影の合併症とし ては統計が行われておらず、詳細を把握していく必要がある。

\section{8 乳癌術後に発生した後腹膜悪性線維性組織球腫の一切}

除例

最成病院 外科、ちば県民保健予防財団 臨床病理科*

藤田和恵、坂田治人、清水英一郎、桑原竹一郎*、鈴木孝雄

悪性線維性組織球症とは、異型性の強い線維芽細胞様細胞と組 織球様細胞からなり、奇異な形の巨細胞や炎症性細胞浸潤を混じ えてきわめて多彩な像を示す悪性度の高い肉腫である。【症例】 67歳時、左乳癌 T $1 \mathrm{~N} 0 \mathrm{M} 0$ に対して乳房円状部分切除術+セン チネルリンパ節生検を施行。9か月後のフォローアップCT検査 にて、左腎上極に腫瘍を認めたものの、myelolipoma と考えられ たため、フォローアップとした。経時的変化にそしく経過してい たが、 2 年後、腫瘍が急速に増大。乳癌の副腎転移や、liposarcomaが疑われた。入院、切除したところ、Myxoid variant malignant fibrous histiocytomaという病理診断であった。現在無再 発生存中である。
9 手術体位撮影画像と局所有茥穿通枝皮弁による再建を 併用した乳房温存術

千葉大学 臓器制御外科

藤本浩司、長嶋 健、榊原雅裕、三階貴史、鈴木浩志、大久保嘉 之、椎名伸充、藤咲 薰、榊原淳太、宮崎 勝

当院では術前の手術時体位画像撮影を用い、手術時に投射再現 することで正確な病変切除を試みている。しかし、切除量が大き ければ、十分な整容性が見込めず、乳房切除＋再建を選択するし かなかった。現在、これらの症例に対し、局所の有茎穿通枝皮弁 による乳房同時部分再建を併用することで温存術でも十分な整容 性を得ることが可能となってきたので報告する。

本法を用いた場合、平均切除標本体積は $104.6 \mathrm{ml}$ であり、従来 法における平均体積 $47.3 \mathrm{ml}$ より有意に増加していたが、十分な整 容性を保つことが可能であった。本法は従来法では整容性保持困 難な温存希望症例に対する選択肢の一つと考えられた。

\section{0}

腹部大動脈瘤および解離性胸部大動脈瘤に対して 3 回 ステントグラフト治療した 1 例

東京慈恵会医科大学附属柏病院外科 ${ }^{1}$ 東京慈恵会医科大学 外 科学講座 血管外科 ${ }^{2}$

百川文健 1 、戸谷直樹1、宿澤孝太 ${ }^{1} 、$ 伏見 淳 1 、高田直樹 1 、菅野 宏1、 藤原佑樹 ${ }^{1}$ 、榎本浩也 、 $^{\text {藤崎宗春 }}$ 、仲田健男 1 、共田光裕 ${ }^{1}$ 三三宅 亮 1 、 稲垣卓也 1 、田中圭一朗 1 、斉藤良太 1 、坪井一人 1 、京田茂也 1 、渡 辺一裕 1 、高橋直人 1 、河原秀次郎 1 、木下智樹 1 、柳澤 暁 1 、三澤 健之 ${ }^{1}$ 、秋葉直志 1 、大木隆生 ${ }^{2}$

症例は50歳代男性. 2012年 4 月, 腹痛のために当科を受診し腹 部大動脈瘤 (AAA) 切迫破裂の診断でステントグラフト内挿術 を施行した，術後経過は良好であったが，2013年 7 月に突然の胸 背部痛が出現した. CTで左鎖骨下動脈末梢にentryを有する Stanford B型急性胸部大動脈解離を認め, 入院降圧治療を行った. 入院後30日目のCTでentryの開存と瘤径拡大を認めたため, 遠 位弓部から下行大動脈にかけて胸部ステントグラフト内挿術を施 行し軽快退院した。術後 3 か月目のCTで胸部ステントグラフト 末梢端に径 $50 \mathrm{~mm}$ の新たな解離性動脈瘤を認めた。再度入院し腹 䏶動脈もカバーするステントグラフトを追加留置し, 対麻痺予防 のために脊髄液ドレナージを併用した。術後は対麻疩もなく経過 良好である. AAA と繰り返す胸部解離性大動脈瘤に対して 3 回 にわたるステントグラフト治療を施行し得た 1 例を経験したので 報告する.

11 人工僧帽弁置換患者の術後に十分なへパリン化を行う も塞栓合併症が多発した 1 例

亀田総合病院 外科

藤井 渉、本城弘貴、草薙 洋

【症例】81歳男性。

【現病歴】右下腹部痛で他院受診し、上行結腸癌による大腸閉塞 で当院に緊急搬送となった。

【既往歴】人工僧帽弁置換術後、脳梗塞、

【内服】ワーファリン、パナルジン、

【入院後経過】ワーファリン休薬後ヘパリン化を開始し、腹腔鏡 下右結腸切除術を施行した。術後 1 日目でヘパリン化を再開とな ったが、術後 4 日目より血便を認めたためワーファリンの再開が できなかった。術後10日目に右上下肢脱力、右半視野欠損を認め、 MRIで左後大脳動脈領域の梗塞が判明した。ヘパリン化は継続 し、術後13日目よりワーファリンを再開したが、術後17日目に腹 
痛を認め、CTでSMA 塞栓症・腎梗塞を認めた。腸管壊死を疑う 所見なかったため、経過観察とし、術後30日目で退院となった。 【考察】特に僧帽弁における機械弁置換術後は塞栓合併症のリス クが高いことが知られている。十分なへパリン化にも関わらず術 後塞栓合併症を多発した一例を経験したため若干の考察を加え報 告する。

12 幹細胞を用いた末梢血管再生治療の検討

国立病院機構千葉東病院 外科

青山博道、西郷健一、長谷川正行、圷尚 武、丸山通広、大月和 宣、松本育子、浅野武秀

【緒言】我々は2004年 6 月から末梢動脈閉塞症に対し血管幹細胞 移植による再生療法を行っている。【目的】治療抵抗性の慢性末 梢動脈閉塞症例に対し骨䯣や末梢血から血管幹細胞を抽出、虚血 肢へ移植し血流改善・肢切断回避・縮小を目的とする。【対象及 び方法】血管形成等観血療法非適応または治療抵抗性重症末梢動 脈閉塞症例を対象とし、調整した骨髄液や末梢血幹細胞を虚血肢 へ移入。【結果】2013年 3 月まで骨䯣細胞・未梢血幹細胞移植計 58例を行い疼痛軽減・冷感消失 (症状の改善)、歩行距離延長を みた。考察】何れの治療法も症状の改善が認められ有効であった。 末梢血幹細胞法は G-CSF投与、骨髄法は腹臥位全身麻酔が必要 であり症例毎の治療法選択が、また治療後の維持療法が重要と考 えられた。

13 閉塞性大腸癌症例に対する stent-laparoscopic approach (sLAP) の有用性

日本医科大学千葉北総病院 外科 ${ }^{1}$, 日本医科大学 消化器外科 ${ }^{2}$ 松田明久 ${ }^{1}$, 松本智司 ${ }^{1}$, 横室茂樹 ${ }^{1}$, 瀬谷知子 ${ }^{1}$, 堀場光二 ${ }^{1}$, 鶴田 宏之 ${ }^{1}$, 櫻澤信行 ${ }^{1}$, 勝野 暁 $^{1}$, 山初和也 ${ }^{1}$, 高橋吾郎 ${ }^{1}$, 下田朋宏 ${ }^{1}$, 菊池友太 ${ }^{1}$, 原絵津子 ${ }^{1}$, 関口久美子 ${ }^{1}$, 宮下正夫 ${ }^{1}$, 内田英二 ${ }^{2}$ 【緒言】当科では, 閉塞大腸癌に対しステント挿入によるsLAP が基本方針。BTS症例（12例）を経肛門減圧管症例（50例）と 比較し有用性を検討。【方法と結果】BTS群および経肛門管群に 扔ける挿入成功率，隇圧成功率はそれぞれ（100\% vs $90 \% ; 100$ \% vs 78\%)。BTS群では, 全例待機的に手術施行。LAP/Open 比は11: 1 。口側腸管の拡張が有意に改善。術後合併症に有意差 なし。【結論】 BTSの長期予後は不明であるが，ステントの良好 な減圧効果を生かしたsLAPは本邦における現在の標準治療であ る経肛門減圧管に代わる可能性がある。 